\title{
Review \\ Cell Ferroptosis: New Mechanism and New Hope for Retinitis Pigmentosa
}

\author{
Ming Yang ${ }^{1} \mathbb{D}$, Kwok-Fai So ${ }^{1,2,3}$, Wai-Ching Lam ${ }^{1, * \mathbb{D}}$ and Amy Cheuk Yin Lo ${ }^{1, * \mathbb{D}}$ \\ 1 Department of Ophthalmology, Li Ka Shing Faculty of Medicine, The University of Hong Kong, \\ Hong Kong 999077, China; hrmeym@connect.hku.hk (M.Y.); hrmaskf@hku.hk (K.-F.S.) \\ 2 State Key Laboratory of Brain and Cognitive Sciences, The University of Hong Kong, \\ Hong Kong 999077, China \\ 3 GHM Institute of CNS Regeneration, Jinan University, Guangzhou 510632, China \\ * Correspondence: waichlam@hku.hk (W.-C.L.); amylo@hku.hk (A.C.Y.L.)
}

check for

updates

Citation: Yang, M.; So, K.-F.; Lam, W.-C.; Lo, A.C.Y. Cell Ferroptosis: New Mechanism and New Hope for Retinitis Pigmentosa. Cells 2021, 10, 2153. https://doi.org/10.3390/ cells10082153

Academic Editor: Paola Bagnoli

Received: 17 June 2021

Accepted: 18 August 2021

Published: 21 August 2021

Publisher's Note: MDPI stays neutral with regard to jurisdictional claims in published maps and institutional affiliations.

Copyright: (c) 2021 by the authors. Licensee MDPI, Basel, Switzerland. This article is an open access article distributed under the terms and conditions of the Creative Commons Attribution (CC BY) license (https:// creativecommons.org/licenses/by/ $4.0 /)$.

\begin{abstract}
Retinitis pigmentosa (RP) is a leading cause of inherited retinal degeneration, with more than 60 gene mutations. Despite the genetic heterogenicity, photoreceptor cell damage remains the hallmark of RP pathology. As a result, RP patients usually suffer from reduced night vision, loss of peripheral vision, decreased visual acuity, and impaired color perception. Although photoreceptor cell death is the primary outcome of RP, the underlying mechanisms are not completely elucidated. Ferroptosis is a novel programmed cell death, with characteristic iron overload and lipid peroxidation. Recent studies, using in vitro and in vivo RP models, discovered the involvement of ferroptosisassociated cell death, suggesting a possible new mechanism for RP pathogenesis. In this review, we discuss the association between ferroptosis and photoreceptor cell damage, and its implication in the pathogenesis of RP. We propose that ferroptotic cell death not only opens up a new research area in $\mathrm{RP}$, but may also serve as a novel therapeutic target for RP.
\end{abstract}

Keywords: eye; homeostasis; ocular stress; regulated cell death; retina; vision

\section{Introduction}

Retinitis pigmentosa (RP) is the most common hereditary and non-nutritional retinal degenerative disease globally [1,2]. It is manifested by the chronic progressive loss of peripheral visual field and electrical potential abnormality, accompanied by reduced vision [2]. Most cases are inherited in an autosomal recessive, autosomal dominant, or X-linked inheritance manner [2,3].

Night blindness, progressive visual field deficiency, decreased central vision, and color vision abnormality, are the major symptoms of RP patients [1]. Night blindness is one of the first characteristic manifestations of RP. Patients may have difficulty seeing or walking at night or in dark places. In addition, an average of about $4.6 \%$ of the visual field is lost every year [4]. Most patients with onset at an early age have a typical progressive narrowing of the visual field, such as "tubular visual field" [5]. The degree of decreased central vision is related to the stages of RP [6]. Although there is no color vision abnormality in the early stage of RP, color vision loss occurs when the visual acuity drops below 0.5 (Log MAR). The typical manifestation is blue blindness; red-green vision disorders are relatively rare.

$\mathrm{RP}$ is diagnosed by genetic testing, electroretinography (ERG), and visual field testing, as well as optical coherence tomography (OCT) $[1,2,5,6]$. Genetic testing enables identification of genes that are associated with RP, to evaluate the possibility of gene therapy. The ERG test provides data on the decreased responsiveness of retinal cells in RP patients. Visual field testing can help to identify peripheral vision loss in RP patients. Using OCT, images of various retinal layers are available, which can help to identify cytoarchitectural abnormalities, such as thinning of the photoreceptor layer [2,6]. Fundus examination could 
also highlight the "triad" of RP, i.e., optic nerve atrophy, narrowed retinal blood vessels, and bone spicules retinal pigmentation [6].

Although photoreceptor cell death is the primary outcome of RP, the underlying mechanisms are not completely elucidated [7]. Ferroptosis is a novel programmed cell death, with the characteristics of iron overload and lipid peroxidation $[8,9]$. Recent studies, using in vitro and in vivo RP models demonstrated features of ferroptosis in photoreceptor cells [10-12], suggesting possible new mechanism in RP pathogenesis. In this review, we discussed the association between ferroptosis and photoreceptor cell damage, and its implication in the pathogenesis of RP. Here, we propose that ferroptotic cell death not only opens up a new research area in RP, but may also serve as a novel therapeutic target for RP.

\section{Overview of Ferroptosis}

Death is the ultimate destination of all cells. In the 19th century, people found that cell death happened when a cell responded to unbearable pressure or damage, either by cell swelling or cell shrinkage; this was later classified into necrosis or apoptosis [13].

Ferroptosis is a new type of programmed cell death, named in 2012 [8]. It plays an important role in a wide range of diseases [9]. Whereas pyroptosis is inflammasome-mediated cell death [14-16], ferroptosis is a form of cell death that is caused by the accumulation of intracellular iron and lipid reactive oxygen species (L-ROS). Intracellular oxidation is the executer of ferroptosis, and is controlled by glutathione peroxidase 4 (GPx-4) [17] or ferroptosis suppressor protein 1 (FSP1) [18,19].

Ferroptosis can be inhibited by antioxidants and iron chelators, but it cannot be inhibited by apoptosis inhibitors [20]. Iron chelating agent, such as deferoxamine (DFO), reduces iron overload and lipid peroxides [21,22]. Ferroptosis is an iron-dependent cell death, characterized by iron overload, with an abnormal increase in lipid reactive oxygen species [23]. Transferrin is an iron-transporting protein, which recognizes and binds to transferrin receptor 1 (TFR1), locates on the cell membrane, to transfer ferric iron $\left(\mathrm{Fe}^{3+}\right)$ from the extracellular environment to the cytoplasm [24]. Recently, TFR has also been considered as a specific ferroptosis marker, which stains ferroptotic cells [25]. STEAP3, a metalloreductase, transforms $\mathrm{Fe}^{3+}$ (insoluble) into $\mathrm{Fe}^{2+}$ (soluble), which is stored in the endosome [26]. When the cell suffers from stress, a large amount $\mathrm{Fe}^{2+}$ is released, through divalent metal transporter 1 (also called DMT1 or SLC11A2), into the cytoplasm, forming a labile iron pool [27]. The released $\mathrm{Fe}^{2+}$ could react with hydrogen peroxide, which is generated from the constant metabolism of the mitochondria, and result in the Fenton reaction, which is a reaction involving hydrogen peroxide and $\mathrm{Fe}^{2+}$ [27]. The Fenton reaction can be written (ferric iron and ferrous are both complexed to ligand " $\mathrm{L}$ ")

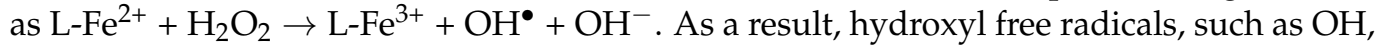
are generated, which leads to a multi-step free radical chain reaction, generating massive lipid-carrying reactive oxygen species (ROS) [28].

Polyunsaturated fatty acid (PUFA) is a major structural component of the cell membrane phospholipid, which is responsible for the fluidity of the cell membrane [29]. It is highly susceptible to oxidative stress and can easily be oxidized. Excessive PUFA oxidation subsequently generates peroxidized phospholipids, which drive ferroptosis [29]. Because of the continuous renewal of the cell membrane, newly made lipids are in constant need to supplement the lipid bilayer. As a result, oxidized PUFA readily enters the cell membrane, causing lipid peroxidation and cell membrane damage.

Glutathione peroxidase $4(\mathrm{GPx}-4)$ is the only enzyme that prevents destructive lipid peroxidation and catalyzes glutathione (GSH), and helps to remove lipid ROS [9]. However, due to the limited source of GSH and the expression of GPx-4, this protective mechanism could not handle massive lipid peroxidation, and, consequently, ferroptosis may happen. Inducers and inhibitors of ferroptosis facilitate the recent development of this subject (Table 1). Here, we review the following two classical pathways of ferroptosis: GSH/GPx-4 and FSP1/CoQ/NADPH. 
Table 1. A summary of molecules for ferroptosis regulation.

\begin{tabular}{|c|c|c|c|c|}
\hline & Classification by Mechanisms & Name & Molecular Weight & References \\
\hline \multirow{13}{*}{ Inducers } & \multirow{3}{*}{ Inhibition of system $\mathrm{X}_{\mathrm{c}}^{-}$} & Erastins & 547.04 & {$[30]$} \\
\hline & & Sorafenib & 464.82 & {$[31]$} \\
\hline & & Sulfasalazine & 398.39 & [32] \\
\hline & Inhibition of cystine consumption & Glutamate & 365.34 & [33] \\
\hline & \multirow{2}{*}{ Inhibition of GPx-4 } & Altretamine & 210.28 & [34] \\
\hline & & $(1 S, 3 R)-R S L 3$ & 440.88 & [17] \\
\hline & \multirow{7}{*}{ Depletion of GSH } & Cisplatin & 300.05 & [35] \\
\hline & & Artesunate & 384.42 & [36] \\
\hline & & DPI2 & 314.55 & [37] \\
\hline & & Buthionine sulfoximine & 222.31 & [38] \\
\hline & & Ferrous chloride & 537.26 & [39] \\
\hline & & Ferrous ammonium sulfate & 392.14 & [40] \\
\hline & & Ferric ammonium citrate & Variable & [41] \\
\hline \multirow{10}{*}{ Inhibitors } & \multirow{7}{*}{ Anti-lipid peroxidation } & Ferrostatin-1 & 262.35 & [42] \\
\hline & & Liproxstatin-1 & 340.85 & [43] \\
\hline & & Vitamin E & 430.71 & {$[44]$} \\
\hline & & SRS 11-92 & 352.47 & [27] \\
\hline & & SRS 16-86 & 432.6 & [45] \\
\hline & & $\mathrm{CoQ}_{10}$ & 863.34 & [18] \\
\hline & & Idebenone & 338.439 & [46] \\
\hline & \multirow{3}{*}{ Reducing iron overload } & Deferoxamine & 560.484 & [47] \\
\hline & & Deferiprone & 139.152 & [23] \\
\hline & & Ciclopirox & 268.35 & [37] \\
\hline
\end{tabular}

System $\mathrm{Xc}^{-}$: the cystine/glutamate transporter/antiporter system; GPx-4: glutathione peroxidase 4; GSH: glutathione; $\mathrm{CoQ}_{10}$ : coenzyme $\mathrm{Q}_{10}$.

\subsection{GSH/GPx-4 Signaling}

The peroxidation of polyunsaturated fatty acid (PUFA) in cells is catalyzed into polyunsaturated fatty acid-containing phospholipids (PL-PUFA (PE)) by acyl-CoA synthetase long-chain family member 4 (ACSL4), generating phospholipid hydroperoxide $(\mathrm{PLOOH})[29]$. PLOOH could trigger the iron-dependent self-amplified Fenton reaction, eventually leading to cell death if not inhibited [48]. However, GPx-4 can effectively reduce phospholipid peroxide and inhibit the production of arachidonic acid (AA), a long-chain fatty acid anion [17]. As GPx-4 is the only enzyme that is responsible for the reduction in $\mathrm{PLOOH}$ in mammalian cells, it plays an indispensable role in protecting cells from oxidative damage [49]. GSH is an essential cofactor for GPx-4; the consumption of GSH in the cell significantly reduces the activity of the GPx-4 enzyme and increases the intracellular lipid hydroxyl radicals. As a result, the accumulation of L-ROS and the oxidation of cell membrane damage lead to ferroptosis [9].

\subsection{FSP1/CoQ/NADPH Signaling}

In 2019, ferroptosis suppressor protein 1 (FSP1) was demonstrated to be a ferroptosis inhibitor, independent of the GSH/GPX4 signaling $[18,19]$. FSP1 was previously known as apoptosis-inducing factor mitochondria-associated 2 (AIFM2). However, due to the lack of an N-terminal mitochondrial targeting sequence in AIFM2, it is neither localized in the mitochondria nor is it a pro-apoptosis protein [19]. Therefore, AIFM2 was recently renamed as FSP1. Bersuker et al. and Doll et al. $[18,19]$ found that FSP1 effectively inhibited 
ferroptosis-independent glutathione and GPx-4 signaling. It can function similarly to NADPH-dependent coenzyme $Q$ (an oxidoreductase), which catalyzes the regeneration of $\mathrm{CoQ}_{10}$, using NADPH. Ubiquinol $\left(\mathrm{CoQ}_{10} \mathrm{H}_{2}\right)$, the reduced form of $\mathrm{CoQ}_{10}$, traps free radicals that are generated by lipid peroxidation, thereby preventing membrane damage $[18,19]$. Further investigation of the FSP1/NADPH/CoQ 10 pathway will be useful for understanding the biological mechanisms that regulate ferroptosis in different diseases.

\subsection{Autophagy Regulates Ferroptosis}

Autophagy is a "self-eating" process that is involved in multiple biological functions $[50,51]$. Correlations between autophagy and ferroptosis have been shown in recent studies. The activation of ferroptotic death depends on the induction of autophagy, and ferroptosis regulatory proteins may also be involved in the regulation of autophagy [52,53].

Cells treated with ferroptosis inducers, such as erastin, increased autophagy, whereas autophagy-deficient cells showed higher cell viability [53]. Excessive activation of intracellular autophagy or lysosomal activity leads to the accumulation of intracellular free iron and lipid peroxides, thereby promoting the occurrence of ferroptosis [54]. In general, autophagy regulates ferroptosis through the following four pathways: ferritinophagy, lipophagy, clockophagy, and chaperone-mediated autophagy.

Ferritinophagy is a prerequisite for ferroptosis [55-57]. Under normal physiological conditions, excessive $\mathrm{Fe}^{2+}$ in the cell is oxidized to $\mathrm{Fe}^{3+}$ by the ferritin heavy-chain subunit (FTH) and, in turn, stored in ferritin or transported out of the cell by the iron transport export protein 1 (ferroprotein 1, FPN1) [9]. It has been shown that nuclear receptor coactivator 4 (NCOA4) interacts with FTH to mediate the autophagic degradation of ferritin [56]. This process is called ferritin autophagy (ferritinophagy). The autophagic degradation of ferritin promotes the release of $\mathrm{Fe}^{3+}$, which causes the increase in free iron in the cells, and thus promotes ferroptosis [58]. The knockdown or knockout of NCOA4, and inhibition the of autophagy, could effectively prevent the occurrence of ferroptosis [58]. Ferritinophagy is required for the induction of ferroptosis, but ferroptosis inducers can promote ferritinophagy as well $[55,59]$ (Figure 1).

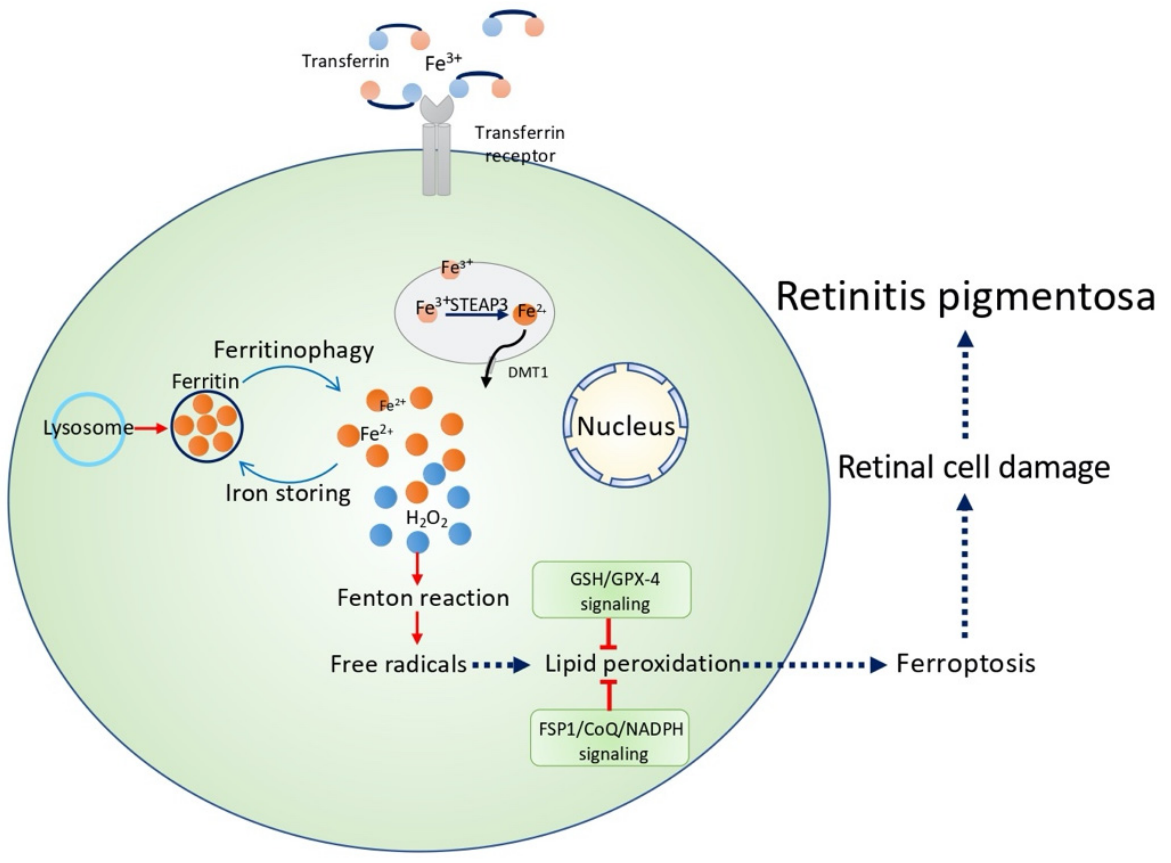

Figure 1. A schematic figure showing ferroptosis as the potential mechanism for retinitis pigmentosa through GSH/GPx-4 signaling or FSP1/CoQ/NADPH signaling.

"Lipophagy" is the degradation process of intracellular lipid droplets, through autophagy [60]. Free fatty acids, generated by lipid autophagy, promote ATP production 
through $\beta$-oxidation in the mitochondria. Current studies have shown that lipophagy promotes RSL3-induced lipid peroxidation and ferroptosis, and the overexpression of tumor protein D52 promotes lipid storage, while inhibiting lipophagy, which effectively inhibits RSL3-induced lipid peroxidation and ferroptosis [61]. However, the potential involvement of other lipid autophagy regulatory proteins in the regulation of ferroptosis is still not fully elucidated.

Clockophagy is a newly discovered autophagy process in 2019 [62]. The circadian clock is endogenous, and can regulate the conversion of circadian rhythm and control many cellular physiological processes, including iron metabolism, oxidative stress, and cell death [63]. Studies have shown that the core protein of the biological clock, aryl hydrocarbon receptor nuclear translocation-like protein 1 (ARNTL1), can be degraded by autophagy, and this process is mediated by p62. This leads to increased expression of hypoxia-inducible factor prolyl hydroxylase 1 (PHD1), thereby promoting intracellular lipid peroxidation and further enhancing ferroptosis [62,63]. As clockophagy happens when there is excessive or impaired autophagy, it is not a normal process.

Chaperone-mediated autophagy (CMA) first entails the recognition of the special amino acid sequence "KFERQ" in the substrate, by the molecular chaperone, which then enters the lysosome by binding to lysosome-associated membrane protein type 2A (LAMP2A), thereby degrading the substrate $[64,65]$. Besides removing lipid peroxides in the cell, to protect it from ferroptosis, GPx-4 also interacts with the heat shock protein family A member 8 (HSPA8), which is a molecular chaperone that is degraded by CMA. The overexpression of LAMP2A promotes CMA to degrade GPx-4, leading to ferroptosis [66-68]. However, contrary to HSPA8, HSPA5 prevents the degradation of GPx-4, by interacting with GPx-4, thereby preventing ferroptosis [67]. The regulatory proteins or factors that are involved in regulating the process of ferroptosis, are also implicated in controlling autophagy (Table 2). Future drugs may be designed for these common regulatory factors, which, at the same time, intervene with autophagy and ferroptosis, to treat RP. However, when designing drugs for these co-regulatory proteins, it is necessary to comprehensively consider the changes in autophagy and ferroptosis in the disease. In addition, how these common regulatory proteins regulate autophagy or ferroptosis, or both, needs further study.

Table 2. Pathways of ferroptosis regulation by autophagy.

\begin{tabular}{cccc}
\hline Type & Mediator & Effect & References \\
\hline Ferritinophagy & NCOA4 & & {$[54]$} \\
Lipophagy & RSL3 & Lipid peroxidation & {$[69]$} \\
Clockophagy & P62, ARNTL, PHD1 & Ferroptosis & {$[62]$} \\
CMA & HSPA8, LAMP2A, GPX-4 & & {$[67]$} \\
\hline
\end{tabular}

\section{Disease Mechanisms of RP}

\subsection{Pathophysiology}

$\mathrm{RP}$ is a retinal degenerative disease in which photoreceptor degeneration (mostly rods and later cones). It is also coined photoreceptor dystrophy [6]. The degeneration originates from the peripheral retina, and progresses to the macula and fovea [70], constricting the visual field [7]. As a result, RP patients develop symptoms such as night blindness, reduced visual field, and decreased vision [71,72]. Abnormal choroidal circulation may also contribute to RP. It is possible to use an electroretinogram (F-ERG), electrooculogram (EOG), and visual evoked potential (P-VEP), to objectively determine whether the choroidal circulation abnormalities affect the retina, macula, or optic nerve $[1,6]$.

\subsection{Genetic Mechanisms}

$\mathrm{RP}$ is a genetic disease [6]. There are three types of inheritance: autosomal recessive, dominant, and sex-linked recessive [73]. The autosomal recessive inheritance is the most prevalent, followed by the dominant and the sex-linked recessive inheritance [74]. Currently, it is believed that the autosomal dominant genetic type has at least 17 gene 
loci located on the short arm of chromosome 1 and the long arm of chromosome 3 [75]. Sex-linked genetic genes are located in the first and second regions of the short arm of the $\mathrm{X}$ chromosome $[3,76]$.

\subsection{Other Molecular Mechanisms}

In recent years, studies found that RP patients have abnormalities in humoral and cellular immunity [77]. Compared with healthy subjects, RP patients carry activated T cells, B cells, and macrophages in the vitreous, while their RPE cells express HLA-DR antigens [78]. In addition, it has been reported that some patients have autoimmunity problems [79], but evidence is insufficient to support this claim. Blood biochemical analysis in RP patients also showed the presence of abnormal lipid metabolism, aberrant trace elements (zinc, copper, selenium) and enzyme metabolism, together with lipofuscin accumulation in the retina [6].

Autophagy has been considered to be a pathological mechanism of RP. It was shown that light-induced damage promoted the expression of visual cytotoxic signaling proteins, leading to retinal degeneration [80]. The knockout of the autophagy gene Agt5 aggravated the accumulation of these proteins, thereby accelerating retinal degeneration. The double knockout of Agt5 and visual transduction protein gene Gnat-1 could lead to a decreased rate of rod cell degeneration, with a well-preserved photoreceptor. Therefore, autophagy may help to clear the visual transduction protein in time, to protect photoreceptors. The Epg5 gene is a unique and highly conserved autophagy gene in multicellular organisms. Epg5 knockout mice also showed progressive retinal neurodegenerative changes in the retina. During the aging process of Epg 5 knockout mice, retinal photoreceptor cells gradually degenerate, which is accompanied by progressive visual dysfunction [81]. Also, the apoptotic activity and the number of apoptotic cells in the ONL of the Epg5 knockout mouse retina, are significantly increased compared with the control group. Therefore, Epg5-deficient mice displays features of RP. These results further support the association of autophagy in the pathogenesis of RP.

\section{Prevention and Intervention Strategies of RP}

$\mathrm{RP}$ is characterized by the irreversible loss of photoreceptor cells, accompanied by RPE cells, and there is no effective treatment for RP yet [82]. For people with impaired vision, a typoscope can be worn to improve their vision for reading. Meanwhile, RPE [83], retinal photoreceptor cell [84], retinal progenitor cell [85], and iris pigment epithelial cell (IPE) [86], have been selected as candidates for cell transplantation, with varying results. Some studies have successfully established the cultivation of photoreceptor cells. While the technique of the sheet transplantation of allogenic photoreceptor cells in animals is successful, there are still doubts about the functional reconstruction [87-90]. Allogenic RPE transplantation can induce the immunological rejection reaction [91], but it is difficult to collect autologous RPE. Therefore, the possibility of replacing RPE with iris pigment epithelial cell (IPE) has been considered and discussed [86,92]. However, this treatment is only for RPE disease, while RP is overwhelmingly a disease of photoreceptor damage. Induced pluripotent stem cell (iPSC) can differentiate to RPE and photoreceptor cells. Transplantation of these derived cells has been shown to rescue light perception and visual function in RCS rats and NOD.SCID-rd1 mice [83]. Another study also demonstrated that the long-term treatment of iPSC-derived RPE and photoreceptor cells effectively protected Pde6b knockout rats [93]. These findings suggest that iPSCs may be a promising therapeutic method for RP.

\subsection{Gene Therapy}

RP has typical genetic heterogeneity. The various pathogenic genes that have been identified, have different inheritance patterns and different gene abnormalities [76,94]. Although the FDA has approved several gene therapy drugs, the presence of a plethora of genes involved in RP, and the difficulty in identifying exact gene mutations, limit the type of gene therapy. On the other hand, RPE65 bi-allelic mutations cause Leber 
congenital amaurosis (LCA), which can also lead to RP [95]. Subretinal injection of adenoassociated virus (AAV) vector, inserted with RPE65 cDNA, repairs this genetic deficiency. In 2017, a phase III clinical trial demonstrated that voretigene neparvovec (AAV2-hRPE65v2) gene therapy showed effective treatment outcomes in 31 patients with RPE 65-mediated inherited retinal dystrophy (ClinicalTrials.gov number, NCT00999609) [96]. This shows that gene therapy is a viable option for some cases of RP.

Meanwhile, hereditary RP is characterized by cell apoptosis, which can be targeted [7]. A first-in-human gene treatment has reported promising safety and efficacy on RPGRmutated X-linked RP, with improved visual acuity and microperimetry [97]. Studies have reported that the inhibition of apoptotic genes and various growth factors, such as brainderived neurotrophic factor (BDNF) [98], basic fibroblast growth factor (bFGF) [99], ciliary neurotrophic factor (CNTF) [100], and glial cell-derived growth factor (GDNF) [101], could delay photoreceptor cell apoptosis. However, the key factors in the pathogenesis and treatment of RP remain to be elucidated.

\subsection{Drug Treatment}

Vitamin A, taurine, and docosahexaenoic acid (DHA) are the most commonly used regimens for abnormal biochemical metabolism in RP patients [102]. They all participate in the maintenance of the normal structure and function of RPE and photoreceptor cells, as well as the normal photoelectric conversion reaction. However, it has been reported that a high dose of vitamin A treatment increased the risk of visual loss, making the value of this type of treatment doubtful [103].

Neurotrophic factors are important for the survival, development, and programmed death of neurons. RPE and Mùller cells release neurotrophic factors, such as CNTF, FGF, transforming growth factor- $\alpha,-\beta$ (TGF- $\alpha,-\beta)$, and platelet-derived growth factor (PDGF), into the intercellular space among photoreceptor cells [104]. Although the concentrations of these factors are low, they induce strong beneficial biological effects, such as cell death prevention and cell growth promotion, rescuing photoreceptors degeneration, and restoring RPE phagocytic function that can help treat RP. Therefore, delivering neurotrophic factors into photoreceptor cells, while minimizing the damage to other tissues of the eye, may be a potential therapy. However, current research on the neurotrophic factors for the treatment of RP is still limited to animal studies.

\subsection{Others}

As strong light accelerates the degeneration of the outer segment of the photoreceptors, sunglasses are important for RP patients. Surgeries using autologous blood vessels to create collaterals, can increase the blood supply to the fundus, which can help photoreceptors in their malnutrition stage, to restore their functions [71]. A healthy lifestyle, such as regular sleeping, not smoking, and a healthy diet, is also essential. Although it is unlikely to accurately predict the individual development of RP, frequent monitoring of RP, by electroretinogram and visual field testing, helps to achieve timely control, preventing further retinal degeneration for early and mid-stage RP patients [105]. Concomitant ophthalmic diseases, such as cataract and cystoid macular edema, which may associate with RP, should also be prevented [106]. For advanced patients, preventing the progression of the disease, and the replacement of degenerated photoreceptor cells or a retina implant, may offer partial sight restoration [107].

To conclude, effective treatment for RP is still lacking. Oral vitamin A, vitamin E, DHA, or neuroprotective factors, may delay photoreceptor cell death, thereby ameliorating the progression of the disease. However, there are controversies regarding the specific efficacy of these drugs.

\section{Association between Ferroptosis and RP}

In spite of the recent signs of progress in ferroptosis study, no systematic reports associating RP and ferroptosis are available yet. However, RP has displayed several 
features that are related to ferroptosis, such as the expression of GPx-4 and GSH, as well as lipid peroxidation (Table 3).

Table 3. Evidence supporting the association between retinitis pigmentosa and ferroptosis.

\begin{tabular}{|c|c|c|c|c|c|c|}
\hline Subject & $\begin{array}{l}\text { Effect on Iron } \\
\text { Homeostasis }\end{array}$ & $\begin{array}{c}\text { Effect on } \\
\text { Ferroptosis- } \\
\text { Associated Protein } \\
\text { Expression }\end{array}$ & $\begin{array}{l}\text { Effect on Oxidative } \\
\text { Stress }\end{array}$ & $\begin{array}{l}\text { Effect on Lipid } \\
\text { Peroxidation }\end{array}$ & $\begin{array}{c}\text { Effect on } \\
\text { Retina/Cell/Mitochondria } \\
\text { Morphology }\end{array}$ & References \\
\hline $\begin{array}{l}\text { Oxidative } \\
\text { damage-induced } \\
\text { retinal degeneration }\end{array}$ & $\mathrm{N} / \mathrm{A}$ & $\begin{array}{l}\text { Decreased GPX4 } \\
\text { expression }\end{array}$ & $\begin{array}{l}\text { Decreased ROS } \\
\text { level and increased } \\
\text { SOD1 expression }\end{array}$ & $\mathrm{N} / \mathrm{A}$ & $\begin{array}{l}\text { Improved retina } \\
\text { thickness and cell loss }\end{array}$ & [108] \\
\hline rd10 mice & $\begin{array}{l}\text { Increased } \\
\text { expressions of } \\
\text { transferrin, ferritin, } \\
\text { ferritin-bound iron, } \\
\text { ceruloplasmin and } \\
\text { total retinal iron }\end{array}$ & $\begin{array}{l}\text { Decreased GPX } \\
\text { expression }\end{array}$ & $\mathrm{N} / \mathrm{A}$ & $\begin{array}{c}\text { Increased HNE } \\
\text { level }\end{array}$ & $\mathrm{N} / \mathrm{A}$ & [11] \\
\hline $\begin{array}{l}\text { Intravitreal injection } \\
\text { of ferrous on wild } \\
\text { type and } r d 10 \text { mice }\end{array}$ & $\mathrm{N} / \mathrm{A}$ & $\begin{array}{l}\text { Decreased GPX } \\
\text { expression }\end{array}$ & $\begin{array}{l}\text { Increased Hmox1, } \\
\text { SOD1 and SOD2 } \\
\text { and oxidative } \\
\text { damage to the } \\
\text { retina }\end{array}$ & $\begin{array}{c}\text { Increased HNE } \\
\text { level }\end{array}$ & $\begin{array}{l}\text { Increased pan-retinal } \\
\text { autofluorescence and } \\
\text { photoreceptor } \\
\text { degeneration }\end{array}$ & [12] \\
\hline $\begin{array}{l}\text { Light-induced } \\
\text { retinal degeneration }\end{array}$ & $\begin{array}{c}\text { Increased } \\
\text { ceruloplasmin }\end{array}$ & N/A & $\begin{array}{l}\text { Increased oxidative } \\
\text { stress }\end{array}$ & N/A & $\begin{array}{l}\text { Increased retinal } \\
\text { structure damage }\end{array}$ & [109] \\
\hline $\begin{array}{l}\text { Sodium } \\
\text { iodate-induced } \\
\text { ARPE-19 damage }\end{array}$ & Increased labile iron & N/A & $\begin{array}{l}\text { Increased oxidative } \\
\text { stress }\end{array}$ & $\begin{array}{l}\text { Increased lipid } \\
\text { peroxidation }\end{array}$ & N/A & [110] \\
\hline $\begin{array}{l}\text { Sodium } \\
\text { iodate-induced } \\
\text { retinal degeneration }\end{array}$ & Increased labile iron & $\begin{array}{l}\text { Decreased GPX-4 } \\
\text { expression }\end{array}$ & $\begin{array}{l}\text { Increased oxidative } \\
\text { stress }\end{array}$ & $\begin{array}{l}\text { Increased lipid } \\
\text { peroxidation }\end{array}$ & $\begin{array}{l}\text { Increased retinal } \\
\text { structure damage }\end{array}$ & [111] \\
\hline
\end{tabular}

\subsection{Potential Involvement of Ferroptosis in RP}

Genetic mutations trigger rod cell death. As a result, oxygen consumption ability is decreased in the outer retina. Together with the redundant oxygen generating oxidative stress, including hydrogen peroxide, this could also cause accumulative oxidative damage to cones, leading to cell death. On the other hand, iron metabolic dysfunction, causing iron accumulation or iron overload, has been reported in RP models [10,11]. A study found the increase levels of both transferrin and transferrin receptors was accompanied by an increased ferritin and ferritin-bound iron level in $r d 10$ mice [11]. Moreover, the level of 4-hydroxy-2-nonenal (4-HNE), a marker of lipid peroxidation, is also significantly increased in the retina [11]. These results suggested the potential involvement of ferroptosis in $r d 10$ mice. However, a link between iron overload and lipid peroxidation is still lacking. A recent study shows that the intravitreal injection of $\mathrm{Fe}^{2+}$ significantly induced photoreceptor oxidative stress and degeneration, while increasing 4-HNE and decreasing GPx-4 level [12]. Based on the theory of ferroptosis, excessive cytoplasm-free iron, together with lipids and hydrogen peroxide, results in the Fenton reaction, producing massive lipid ROS, causing lipid peroxidation. This evidence supports a possible involvement of ferroptosis in RP.

\subsection{Ferroptosis Regulation in $R P$}

Increasing evidence, showing the regulation of ferroptosis, has a great potential for RP treatment. In 2009, there was a breakthrough study, showing that the overexpression of GPX-4 strongly protected the retina in three models of oxidative damage-induced retinal degeneration [108]. Moreover, iron chelators, well-recognized ferroptosis inhibitors, show protective effects in several RP models. In 2011, a study demonstrated that zincdesferrioxamine significantly alleviated retinal degeneration in $r d 10$ mice [112]. Also, in the same RP model, two other iron-chelating drugs, including VK28 and VAR10303, were shown to promote cone photoreceptor survival, suggesting that chelating labile iron is a novel treatment option for RP [113]. In 2013, a study also illustrated that an iron chelator deferiprone decreased oxidative stress, thereby protecting the degeneration of the light-exposed photoreceptor in mice [109]. These studies together suggest the potential of iron regulation in RP treatment. However, data on other ferroptosis regulators, such as ferrostatin- 1 and liproxstatin-1 on RP models, are still lacking. Recently, two new 
studies found that ferroptosis is involved in sodium iodate-induced ARPE-19 cell death, suggesting that ferroptosis is involved in retinal degeneration, which supports the association with RP $[110,111]$. They first observed that sodium iodate increased intracellular labile iron, while decreasing intracellular glutathione and cysteine. Using deferoxamine or ferrostatin-1, two ferroptosis inhibitors, ARPE-19 cell death was prevented from sodium iodate exposure $[110,111]$. These studies together support the relatively strong association between RP and ferroptosis (Figure 1). However, further studies on ferroptosis are essential.

\section{Ferroptosis: A New Future Therapeutic Target for RP?}

Although gene therapy, drug treatment, and iPSCs are available for RP, they might still have some disadvantages. Current therapeutic options are nonetheless limited. Therefore, it is important to seek alternative choices, by uncovering novel mechanisms of RP. Ferroptosis is closely associated with RP pathogenesis. Therefore, it would be worthwhile to investigate whether anti-ferroptotic events, such as decreasing iron overload, increasing the level of anti-oxidants, and reducing lipid peroxidation, could rescue photoreceptors in RP. Apart from using iron chelators, increasing the expressions of GSH and GPX-4, while decreasing ACSL-4, could be helpful to further evaluate the role of ferroptosis in RP pathogenesis.

As shown in the previous section, ferroptosis is regulated by autophagy in some diseases, such as cancer and neurodegeneration [114]. Evidence also supports the important role of autophagy in maintaining photoreceptor homeostasis. Therefore, it may be possible to control ferroptosis in RP by regulating autophagy.

\section{Conclusions and Future Remarks}

$\mathrm{RP}$ is a hereditary eye disease. The current FDA-approved gene therapies are expensive. They are effective in young patients, but a personalized regimen is not feasible, due to the large genetic variations in RP. There is still a lack of good therapeutic strategies that effectively delay the progression of RP and preserve the patients' vision. Numerous attempts have been tried, to find neuroprotective drugs (neurotrophic factors, anti-oxidants, and anti-apoptotic factors), but they all have limitations and complications.

In summary, the search for novel mechanisms of photoreceptor cell death, such as ferroptosis, may contribute to our understanding of $\mathrm{RP}$ and provide new directions for its treatment.

Author Contributions: M.Y. Conceptualization; data curation; formal analysis; investigation; methodology; validation; visualization; writing—original draft; writing—review and editing. K.-F.S. Supervision; writing - review and editing. W.-C.L. Funding acquisition; project administration; resources; supervision; writing - review and editing. A.C.Y.L. Conceptualization; data curation; formal analysis; investigation; methodology; project administration; supervision; validation; visualization; writingoriginal draft; writing - review and editing. All authors have read and agreed to the published version of the manuscript.

Funding: This study is supported by Albert Bing-Ching Young Professorship Endowment in Ophthalmology to WC Lam; Health and Medical Research Fund, the Food and Health Bureau, The Government of the Hong Kong Special Administrative Region (06171516) and General Research Fund, Research Grants Council, The Government of the Hong Kong Special Administrative Region (17112919) to ACY Lo.

Institutional Review Board Statement: Not applicable.

Informed Consent Statement: Not applicable.

Data Availability Statement: Not applicable.

Acknowledgments: The authors thank Ching-Lung Lai (Department of Medicine, The University of Hong Kong) for his editorial assistance in this manuscript.

Conflicts of Interest: The authors declare no conflict of interest. 


\section{References}

1. Hartong, D.T.; Berson, E.L.; Dryja, T.P. Retinitis pigmentosa. Lancet 2006, 368, 1795-1809. [CrossRef]

2. Fahim, A. Retinitis pigmentosa: Recent advances and future directions in diagnosis and management. Curr. Opin. Pediatr. 2018, 30, 725-733. [CrossRef]

3. Daiger, S.P.; Sullivan, L.S.; Bowne, S.J. Genes and mutations causing retinitis pigmentosa. Clin. Genet. 2013, 84, 132-141. [CrossRef] [PubMed]

4. Nowomiejska, K.; Brzozowska, A.; Koss, M.J.; Weleber, R.G.; Schiefer, U.; Rejdak, K.; Juenemann, A.G.; Maciejewski, R.; Rejdak, R. Quantification of the Visual Field Loss in Retinitis Pigmentosa Using Semi-Automated Kinetic Perimetry. Curr. Eye Res. 2016, 41, 993-998. [CrossRef] [PubMed]

5. Grover, S.; Fishman, G.A.; Brown, J., Jr. Patterns of visual field progression in patients with retinitis pigmentosa. Ophthalmology 1998, 105, 1069-1075. [CrossRef]

6. O'Neal, T.B.; Luther, E.E. Retinitis Pigmentosa; StatPearls: Treasure Island, FL, USA, 2021.

7. Newton, F.; Megaw, R. Mechanisms of Photoreceptor Death in Retinitis Pigmentosa. Genes 2020, 11, 1120. [CrossRef] [PubMed]

8. Dixon, S.J.; Lemberg, K.M.; Lamprecht, M.R.; Skouta, R.; Zaitsev, E.M.; Gleason, C.E.; Patel, D.N.; Bauer, A.J.; Cantley, A.M.; Yang, W.S.; et al. Ferroptosis: An iron-dependent form of nonapoptotic cell death. Cell 2012, 149, 1060-1072. [CrossRef]

9. Jiang, X.; Stockwell, B.R.; Conrad, M. Ferroptosis: Mechanisms, biology and role in disease. Nat. Rev. Mol. Cell Biol. 2021, 22, 266-282. [CrossRef]

10. He, X.; Hahn, P.; Iacovelli, J.; Wong, R.; King, C.; Bhisitkul, R.; Massaro-Giordano, M.; Dunaief, J.L. Iron homeostasis and toxicity in retinal degeneration. Prog. Retin. Eye Res. 2007, 26, 649-673. [CrossRef]

11. Deleon, E.; Lederman, M.; Berenstein, E.; Meir, T.; Chevion, M.; Chowers, I. Alteration in iron metabolism during retinal degeneration in rd10 mouse. Investig. Ophthalmol. Vis. Sci. 2009, 50, 1360-1365. [CrossRef] [PubMed]

12. Shu, W.; Baumann, B.H.; Song, Y.; Liu, Y.; Wu, X.; Dunaief, J.L. Ferrous but not ferric iron sulfate kills photoreceptors and induces photoreceptor-dependent RPE autofluorescence. Redox Biol. 2020, 34, 101469. [CrossRef]

13. Grootjans, S.; Vanden Berghe, T.; Vandenabeele, P. Initiation and execution mechanisms of necroptosis: An overview. Cell Death Differ. 2017, 24, 1184-1195. [CrossRef] [PubMed]

14. Yang, M.; So, K.F.; Lam, W.C.; Lo, A.C.Y. Novel Programmed Cell Death as Therapeutic Targets in Age-Related Macular Degeneration? Int. J. Mol. Sci. 2020, 21, 7279. [CrossRef] [PubMed]

15. Yang, M.; So, K.F.; Lo, A.C.Y.; Lam, W.C. The Effect of Lycium barbarum Polysaccharides on Pyroptosis-Associated Amyloid beta1-40 Oligomers-Induced Adult Retinal Pigment Epithelium 19 Cell Damage. Int. J. Mol. Sci. 2020, 21, 4658. [CrossRef] [PubMed]

16. Man, S.M.; Karki, R.; Kanneganti, T.D. Molecular mechanisms and functions of pyroptosis, inflammatory caspases and inflammasomes in infectious diseases. Immunol. Rev. 2017, 277, 61-75. [CrossRef]

17. Yang, W.S.; SriRamaratnam, R.; Welsch, M.E.; Shimada, K.; Skouta, R.; Viswanathan, V.S.; Cheah, J.H.; Clemons, P.A.; Shamji, A.F.; Clish, C.B.; et al. Regulation of ferroptotic cancer cell death by GPX4. Cell 2014, 156, 317-331. [CrossRef]

18. Doll, S.; Freitas, F.P.; Shah, R.; Aldrovandi, M.; da Silva, M.C.; Ingold, I.; Goya Grocin, A.; Xavier da Silva, T.N.; Panzilius, E.; Scheel, C.H.; et al. FSP1 is a glutathione-independent ferroptosis suppressor. Nature 2019, 575, 693-698. [CrossRef]

19. Bersuker, K.; Hendricks, J.M.; Li, Z.; Magtanong, L.; Ford, B.; Tang, P.H.; Roberts, M.A.; Tong, B.; Maimone, T.J.; Zoncu, R.; et al. The CoQ oxidoreductase FSP1 acts parallel to GPX4 to inhibit ferroptosis. Nature 2019, 575, 688-692. [CrossRef]

20. Li, J.; Cao, F.; Yin, H.L.; Huang, Z.J.; Lin, Z.T.; Mao, N.; Sun, B.; Wang, G. Ferroptosis: Past, present and future. Cell Death Dis. 2020, 11, 88. [CrossRef]

21. Angeli, J.P.F.; Shah, R.; Pratt, D.A.; Conrad, M. Ferroptosis Inhibition: Mechanisms and Opportunities. Trends Pharmacol. Sci. 2017, 38, 489-498. [CrossRef]

22. Yang, M.; Lai, C.L. SARS-CoV-2 infection: Can ferroptosis be a potential treatment target for multiple organ involvement? Cell Death Discov. 2020, 6, 130. [CrossRef]

23. Stockwell, B.R.; Friedmann Angeli, J.P.; Bayir, H.; Bush, A.I.; Conrad, M.; Dixon, S.J.; Fulda, S.; Gascon, S.; Hatzios, S.K.; Kagan, V.E.; et al. Ferroptosis: A Regulated Cell Death Nexus Linking Metabolism, Redox Biology, and Disease. Cell 2017, 171, 273-285. [CrossRef]

24. Bartnikas, T.B. Known and potential roles of transferrin in iron biology. Biometals 2012, 25, 677-686. [CrossRef]

25. Feng, H.; Schorpp, K.; Jin, J.; Yozwiak, C.E.; Hoffstrom, B.G.; Decker, A.M.; Rajbhandari, P.; Stokes, M.E.; Bender, H.G.; Csuka, J.M.; et al. Transferrin Receptor Is a Specific Ferroptosis Marker. Cell Rep. 2020, 30, 3411-3423.e7. [CrossRef] [PubMed]

26. Zhang, F.; Tao, Y.; Zhang, Z.; Guo, X.; An, P.; Shen, Y.; Wu, Q.; Yu, Y.; Wang, F. Metalloreductase Steap3 coordinates the regulation of iron homeostasis and inflammatory responses. Haematologica 2012, 97, 1826-1835. [CrossRef] [PubMed]

27. Xie, Y.; Hou, W.; Song, X.; Yu, Y.; Huang, J.; Sun, X.; Kang, R.; Tang, D. Ferroptosis: Process and function. Cell Death Differ. 2016, 23, 369-379. [CrossRef] [PubMed]

28. Winterbourn, C.C. Toxicity of iron and hydrogen peroxide: The Fenton reaction. Toxicol. Lett. 1995, 82-83, 969-974. [CrossRef]

29. Yang, W.S.; Kim, K.J.; Gaschler, M.M.; Patel, M.; Shchepinov, M.S.; Stockwell, B.R. Peroxidation of polyunsaturated fatty acids by lipoxygenases drives ferroptosis. Proc. Natl. Acad. Sci. USA 2016, 113, E4966-E4975. [CrossRef]

30. Yang, Y.; Luo, M.; Zhang, K.; Zhang, J.; Gao, T.; Connell, D.O.; Yao, F.; Mu, C.; Cai, B.; Shang, Y.; et al. Nedd4 ubiquitylates VDAC2/3 to suppress erastin-induced ferroptosis in melanoma. Nat. Commun. 2020, 11, 433. [CrossRef] 
31. Sun, X.; Niu, X.; Chen, R.; He, W.; Chen, D.; Kang, R.; Tang, D. Metallothionein-1G facilitates sorafenib resistance through inhibition of ferroptosis. Hepatology 2016, 64, 488-500. [CrossRef]

32. Yu, H.; Yang, C.; Jian, L.; Guo, S.; Chen, R.; Li, K.; Qu, F.; Tao, K.; Fu, Y.; Luo, F.; et al. Sulfasalazineinduced ferroptosis in breast cancer cells is reduced by the inhibitory effect of estrogen receptor on the transferrin receptor. Oncol. Rep. 2019, 42, 826-838. [CrossRef] [PubMed]

33. Kang, Y.P.; Mockabee-Macias, A.; Jiang, C.; Falzone, A.; Prieto-Farigua, N.; Stone, E.; Harris, I.S.; DeNicola, G.M. Non-canonical Glutamate-Cysteine Ligase Activity Protects against Ferroptosis. Cell Metab. 2021, 33, 174-189.e177. [CrossRef] [PubMed]

34. Lei, P.; Bai, T.; Sun, Y. Mechanisms of Ferroptosis and Relations With Regulated Cell Death: A Review. Front. Physiol. 2019, 10, 139. [CrossRef]

35. Hu, Z.; Zhang, H.; Yi, B.; Yang, S.; Liu, J.; Hu, J.; Wang, J.; Cao, K.; Zhang, W. VDR activation attenuate cisplatin induced AKI by inhibiting ferroptosis. Cell Death Dis. 2020, 11, 73. [CrossRef]

36. Roh, J.L.; Kim, E.H.; Jang, H.; Shin, D. Nrf2 inhibition reverses the resistance of cisplatin-resistant head and neck cancer cells to artesunate-induced ferroptosis. Redox Biol. 2017, 11, 254-262. [CrossRef] [PubMed]

37. Hassannia, B.; Vandenabeele, P.; Vanden Berghe, T. Targeting Ferroptosis to Iron Out Cancer. Cancer Cell 2019, 35, 830-849. [CrossRef]

38. Hoshino, T.; Yamakado, H.; Takahashi, R.; Matsuzawa, S.I. Susceptibility to erastin-induced ferroptosis decreases during maturation in a human oligodendrocyte cell line. FEBS Open Bio 2020, 10, 1758-1764. [CrossRef]

39. Li, W.; Li, W.; Leng, Y.; Xiong, Y.; Xia, Z. Ferroptosis Is Involved in Diabetes Myocardial Ischemia/Reperfusion Injury Through Endoplasmic Reticulum Stress. DNA Cell Biol. 2020, 39, 210-225. [CrossRef]

40. Yang, W.S.; Stockwell, B.R. Ferroptosis: Death by Lipid Peroxidation. Trends Cell Biol. 2016, 26, 165-176. [CrossRef]

41. Fang, S.; Yu, X.; Ding, H.; Han, J.; Feng, J. Effects of intracellular iron overload on cell death and identification of potent cell death inhibitors. Biochem. Biophys. Res. Commun. 2018, 503, 297-303. [CrossRef]

42. Miotto, G.; Rossetto, M.; Di Paolo, M.L.; Orian, L.; Venerando, R.; Roveri, A.; Vuckovic, A.M.; Bosello Travain, V.; Zaccarin, M.; Zennaro, L.; et al. Insight into the mechanism of ferroptosis inhibition by ferrostatin-1. Redox Biol. 2020, 28, 101328. [CrossRef]

43. Fan, B.Y.; Pang, Y.L.; Li, W.X.; Zhao, C.X.; Zhang, Y.; Wang, X.; Ning, G.Z.; Kong, X.H.; Liu, C.; Yao, X.; et al. Liproxstatin-1 is an effective inhibitor of oligodendrocyte ferroptosis induced by inhibition of glutathione peroxidase 4. Neural Regen. Res. 2021, 16, 561-566. [CrossRef]

44. Tavakol, S.; Seifalian, A.M. Vitamin E at a high dose as an anti-ferroptosis drug and not just a supplement for COVID-19 treatment. Biotechnol. Appl. Biochem. 2021. [CrossRef]

45. Zhang, Y.; Sun, C.; Zhao, C.; Hao, J.; Zhang, Y.; Fan, B.; Li, B.; Duan, H.; Liu, C.; Kong, X.; et al. Ferroptosis inhibitor SRS 16-86 attenuates ferroptosis and promotes functional recovery in contusion spinal cord injury. Brain Res. 2019, 1706, 48-57. [CrossRef]

46. Kuang, F.; Liu, J.; Tang, D.; Kang, R. Oxidative Damage and Antioxidant Defense in Ferroptosis. Front. Cell Dev. Biol. 2020, 8, 586578. [CrossRef]

47. Zhang, Y.; Fan, B.Y.; Pang, Y.L.; Shen, W.Y.; Wang, X.; Zhao, C.X.; Li, W.X.; Liu, C.; Kong, X.H.; Ning, G.Z.; et al. Neuroprotective effect of deferoxamine on erastininduced ferroptosis in primary cortical neurons. Neural Regen. Res. 2020, 15, 1539-1545. [CrossRef]

48. Imai, H.; Nakagawa, Y. Biological significance of phospholipid hydroperoxide glutathione peroxidase (PHGPx, GPx4) in mammalian cells. Free Radic. Biol. Med. 2003, 34, 145-169. [CrossRef]

49. Seibt, T.M.; Proneth, B.; Conrad, M. Role of GPX4 in ferroptosis and its pharmacological implication. Free Radic. Biol. Med. 2019, 133, 144-152. [CrossRef] [PubMed]

50. Yang, M.; Wen, T.; Chen, H.; Deng, J.; Yang, C.; Zhang, Z. Knockdown of insulin-like growth factor 1 exerts a protective effect on hypoxic injury of aged BM-MSCs: Role of autophagy. Stem Cell Res. Ther. 2018, 9, 284. [CrossRef]

51. Dikic, I.; Elazar, Z. Mechanism and medical implications of mammalian autophagy. Nat. Rev. Mol. Cell Biol. 2018, 19, 349-364. [CrossRef] [PubMed]

52. Zhou, Y.; Shen, Y.; Chen, C.; Sui, X.; Yang, J.; Wang, L.; Zhou, J. The crosstalk between autophagy and ferroptosis: What can we learn to target drug resistance in cancer? Cancer Biol. Med. 2019, 16, 630-646. [CrossRef]

53. Gao, M.; Monian, P.; Pan, Q.; Zhang, W.; Xiang, J.; Jiang, X. Ferroptosis is an autophagic cell death process. Cell Res. 2016, 26, 1021-1032. [CrossRef]

54. Hou, W.; Xie, Y.; Song, X.; Sun, X.; Lotze, M.T.; Zeh, H.J., 3rd; Kang, R.; Tang, D. Autophagy promotes ferroptosis by degradation of ferritin. Autophagy 2016, 12, 1425-1428. [CrossRef]

55. Tang, M.; Chen, Z.; Wu, D.; Chen, L. Ferritinophagy/ferroptosis: Iron-related newcomers in human diseases. J. Cell Physiol. 2018, 233, 9179-9190. [CrossRef]

56. Sui, S.; Zhang, J.; Xu, S.; Wang, Q.; Wang, P.; Pang, D. Ferritinophagy is required for the induction of ferroptosis by the bromodomain protein BRD4 inhibitor (+)-JQ1 in cancer cells. Cell Death Dis. 2019, 10, 331. [CrossRef]

57. Latunde-Dada, G.O. Ferroptosis: Role of lipid peroxidation, iron and ferritinophagy. Biochim. Biophys. Acta Gen. Subj. 2017, 1861, 1893-1900. [CrossRef] [PubMed]

58. Yoshida, M.; Minagawa, S.; Araya, J.; Sakamoto, T.; Hara, H.; Tsubouchi, K.; Hosaka, Y.; Ichikawa, A.; Saito, N.; Kadota, T.; et al. Involvement of cigarette smoke-induced epithelial cell ferroptosis in COPD pathogenesis. Nat. Commun. 2019, 10, 3145. [CrossRef] [PubMed] 
59. Gryzik, M.; Asperti, M.; Denardo, A.; Arosio, P.; Poli, M. NCOA4-mediated ferritinophagy promotes ferroptosis induced by erastin, but not by RSL3 in HeLa cells. Biochim. Biophys. Acta Mol. Cell Res. 2021, 1868, 118913. [CrossRef] [PubMed]

60. Singh, R.; Cuervo, A.M. Lipophagy: Connecting autophagy and lipid metabolism. Int. J. Cell Biol. 2012, 2012, 282041. [CrossRef] [PubMed]

61. Bai, Y.; Meng, L.; Han, L.; Jia, Y.; Zhao, Y.; Gao, H.; Kang, R.; Wang, X.; Tang, D.; Dai, E. Lipid storage and lipophagy regulates ferroptosis. Biochem. Biophys. Res. Commun. 2019, 508, 997-1003. [CrossRef] [PubMed]

62. Yang, M.; Chen, P.; Liu, J.; Zhu, S.; Kroemer, G.; Klionsky, D.J.; Lotze, M.T.; Zeh, H.J.; Kang, R.; Tang, D. Clockophagy is a novel selective autophagy process favoring ferroptosis. Sci. Adv. 2019, 5, eaaw2238. [CrossRef]

63. Liu, J.; Yang, M.; Kang, R.; Klionsky, D.J.; Tang, D. Autophagic degradation of the circadian clock regulator promotes ferroptosis Autophagy 2019, 15, 2033-2035. [CrossRef] [PubMed]

64. Dice, J.F. Chaperone-mediated autophagy. Autophagy 2007, 3, 295-299. [CrossRef] [PubMed]

65. Cuervo, A.M.; Wong, E. Chaperone-mediated autophagy: Roles in disease and aging. Cell Res. 2014, 24, 92-104. [CrossRef] [PubMed]

66. Wu, Z.; Geng, Y.; Lu, X.; Shi, Y.; Wu, G.; Zhang, M.; Shan, B.; Pan, H.; Yuan, J. Chaperone-mediated autophagy is involved in the execution of ferroptosis. Proc. Natl. Acad. Sci. USA 2019, 116, 2996-3005. [CrossRef]

67. Chen, X.; Yu, C.; Kang, R.; Kroemer, G.; Tang, D. Cellular degradation systems in ferroptosis. Cell Death Differ. 2021, 28, 1135-1148. [CrossRef]

68. Chen, C.; Wang, D.; Yu, Y.; Zhao, T.; Min, N.; Wu, Y.; Kang, L.; Zhao, Y.; Du, L.; Zhang, M.; et al. Legumain promotes tubular ferroptosis by facilitating chaperone-mediated autophagy of GPX4 in AKI. Cell Death Dis. 2021, 12, 65. [CrossRef]

69. Sui, X.; Zhang, R.; Liu, S.; Duan, T.; Zhai, L.; Zhang, M.; Han, X.; Xiang, Y.; Huang, X.; Lin, H.; et al. RSL3 Drives Ferroptosis Through GPX4 Inactivation and ROS Production in Colorectal Cancer. Front. Pharmacol. 2018, 9, 1371. [CrossRef]

70. Sorrentino, F.S.; Gallenga, C.E.; Bonifazzi, C.; Perri, P. A challenge to the striking genotypic heterogeneity of retinitis pigmentosa: A better understanding of the pathophysiology using the newest genetic strategies. Eye 2016, 30, 1542-1548. [CrossRef]

71. Yang, Y.J.; Peng, J.; Ying, D.; Peng, Q.H. A Brief Review on the Pathological Role of Decreased Blood Flow Affected in Retinitis Pigmentosa. J. Ophthalmol. 2018, 2018, 3249064. [CrossRef]

72. Lakkaraju, A.; Umapathy, A.; Tan, L.X.; Daniele, L.; Philp, N.J.; Boesze-Battaglia, K.; Williams, D.S. The cell biology of the retinal pigment epithelium. Prog. Retin. Eye Res. 2020, 78, 100846. [CrossRef] [PubMed]

73. Bravo-Gil, N.; Gonzalez-Del Pozo, M.; Martin-Sanchez, M.; Mendez-Vidal, C.; Rodriguez-de la Rua, E.; Borrego, S.; Antinolo, G. Unravelling the genetic basis of simplex Retinitis Pigmentosa cases. Sci. Rep. 2017, 7, 41937. [CrossRef] [PubMed]

74. Riazuddin, S.A.; Zulfiqar, F.; Zhang, Q.; Sergeev, Y.V.; Qazi, Z.A.; Husnain, T.; Caruso, R.; Riazuddin, S.; Sieving, P.A.; Hejtmancik, J.F. Autosomal recessive retinitis pigmentosa is associated with mutations in RP1 in three consanguineous Pakistani families. Invest. Ophthalmol. Vis. Sci. 2005, 46, 2264-2270. [CrossRef] [PubMed]

75. Ferrari, S.; Di Iorio, E.; Barbaro, V.; Ponzin, D.; Sorrentino, F.S.; Parmeggiani, F. Retinitis pigmentosa: Genes and disease mechanisms. Curr. Genom. 2011, 12, 238-249. [CrossRef]

76. Ducloyer, J.B.; Le Meur, G.; Cronin, T.; Adjali, O.; Weber, M. Gene therapy for retinitis pigmentosa. Med. Sci. 2020, 36, 607-615. [CrossRef]

77. McMurtrey, J.J.; Tso, M.O.M. A review of the immunologic findings observed in retinitis pigmentosa. Surv. Ophthalmol. 2018, 63, 769-781. [CrossRef]

78. Newsome, D.A.; Michels, R.G. Detection of lymphocytes in the vitreous gel of patients with retinitis pigmentosa. Am. J. Ophthalmol. 1988, 105, 596-602. [CrossRef]

79. Ten Berge, J.C.; Fazil, Z.; van den Born, I.; Wolfs, R.C.W.; Schreurs, M.W.J.; Dik, W.A.; Rothova, A. Intraocular cytokine profile and autoimmune reactions in retinitis pigmentosa, age-related macular degeneration, glaucoma and cataract. Acta Ophthalmol. 2019, 97, 185-192. [CrossRef]

80. Yao, J.; Jia, L.; Feathers, K.; Lin, C.; Khan, N.W.; Klionsky, D.J.; Ferguson, T.A.; Zacks, D.N. Autophagy-mediated catabolism of visual transduction proteins prevents retinal degeneration. Autophagy 2016, 12, 2439-2450. [CrossRef]

81. Miao, G.; Zhao, Y.G.; Zhao, H.; Ji, C.; Sun, H.; Chen, Y.; Zhang, H. Mice deficient in the Vici syndrome gene Epg5 exhibit features of retinitis pigmentosa. Autophagy 2016, 12, 2263-2270. [CrossRef]

82. Wang, A.L.; Knight, D.K.; Vu, T.T.; Mehta, M.C. Retinitis Pigmentosa: Review of Current Treatment. Int. Ophthalmol. Clin. 2019, 59, 263-280. [CrossRef] [PubMed]

83. Surendran, H.; Nandakumar, S.; Reddy, K.V.; Stoddard, J.; Mohan, K.V.; Upadhyay, P.K.; McGill, T.J.; Pal, R. Transplantation of retinal pigment epithelium and photoreceptors generated concomitantly via small molecule-mediated differentiation rescues visual function in rodent models of retinal degeneration. Stem Cell Res. Ther. 2021, 12, 70. [CrossRef] [PubMed]

84. Reh, T.A. Photoreceptor Transplantation in Late Stage Retinal Degeneration. Investig. Ophthalmol. Vis. Sci. 2016, 57, ORSFg1-ORSFg7. [CrossRef] [PubMed]

85. Kagan, V.E.; Mao, G.; Qu, F.; Angeli, J.P.; Doll, S.; Croix, C.S.; Dar, H.H.; Liu, B.; Tyurin, V.A.; Ritov, V.B.; et al. Oxidized arachidonic and adrenic PEs navigate cells to ferroptosis. Nat. Chem. Biol. 2017, 13, 81-90. [CrossRef] [PubMed]

86. Abe, T.; Yoshida, M.; Yoshioka, Y.; Wakusawa, R.; Tokita-Ishikawa, Y.; Seto, H.; Tamai, M.; Nishida, K. Iris pigment epithelial cell transplantation for degenerative retinal diseases. Prog. Retin. Eye Res. 2007, 26, 302-321. [CrossRef] [PubMed] 
87. Gasparini, S.J.; Llonch, S.; Borsch, O.; Ader, M. Transplantation of photoreceptors into the degenerative retina: Current state and future perspectives. Prog. Retin. Eye Res. 2019, 69, 1-37. [CrossRef]

88. Borsch, O.; Santos-Ferreira, T.; Ader, M. Photoreceptor Transplantation into the Degenerative Retina. Klin Monbl Augenheilkd 2017, 234, 343-353. [CrossRef]

89. Singh, M.S.; Park, S.S.; Albini, T.A.; Canto-Soler, M.V.; Klassen, H.; MacLaren, R.E.; Takahashi, M.; Nagiel, A.; Schwartz, S.D.; Bharti, K. Retinal stem cell transplantation: Balancing safety and potential. Prog. Retin. Eye Res. 2020, 75, 100779. [CrossRef]

90. Lorach, H.; Kang, S.; Bhuckory, M.B.; Trouillet, A.; Dalal, R.; Marmor, M.; Palanker, D. Transplantation of Mature Photoreceptors in Rodents With Retinal Degeneration. Transl. Vis. Sci. Technol. 2019, 8, 30. [CrossRef]

91. Radtke, N.D.; Aramant, R.B.; Seiler, M.J.; Petry, H.M.; Pidwell, D. Vision change after sheet transplant of fetal retina with retinal pigment epithelium to a patient with retinitis pigmentosa. Arch. Ophthalmol. 2004, 122, 1159-1165. [CrossRef] [PubMed]

92. Cai, H.; Shin, M.C.; Tezel, T.H.; Kaplan, H.J.; Del Priore, L.V. Use of iris pigment epithelium to replace retinal pigment epithelium in age-related macular degeneration: A gene expression analysis. Arch. Ophthalmol. 2006, 124, 1276-1285. [CrossRef]

93. Yang, J.M.; Chung, S.; Yun, K.; Kim, B.; So, S.; Kang, S.; Kang, E.; Lee, J.Y. Long-term effects of human induced pluripotent stem cell-derived retinal cell transplantation in Pde6b knockout rats. Exp. Mol. Med. 2021, 53, 631-642. [CrossRef] [PubMed]

94. Dejneka, N.S.; Bennett, J. Gene therapy and retinitis pigmentosa: Advances and future challenges. Bioessays 2001, 23, 662-668. [CrossRef] [PubMed]

95. Srilekha, S.; Arokiasamy, T.; Srikrupa, N.N.; Umashankar, V.; Meenakshi, S.; Sen, P.; Kapur, S.; Soumittra, N. Homozygosity Mapping in Leber Congenital Amaurosis and Autosomal Recessive Retinitis Pigmentosa in South Indian Families. PLoS ONE 2015, 10, e0131679. [CrossRef]

96. Russell, S.; Bennett, J.; Wellman, J.A.; Chung, D.C.; Yu, Z.F.; Tillman, A.; Wittes, J.; Pappas, J.; Elci, O.; McCague, S.; et al. Efficacy and safety of voretigene neparvovec (AAV2-hRPE65v2) in patients with RPE65-mediated inherited retinal dystrophy: A randomised, controlled, open-label, phase 3 trial. Lancet 2017, 390, 849-860. [CrossRef]

97. Cehajic-Kapetanovic, J.; Xue, K.; Martinez-Fernandez de la Camara, C.; Nanda, A.; Davies, A.; Wood, L.J.; Salvetti, A.P.; Fischer, M.D.; Aylward, J.W.; Barnard, A.R.; et al. Initial results from a first-in-human gene therapy trial on X-linked retinitis pigmentosa caused by mutations in RPGR. Nat. Med. 2020, 26, 354-359. [CrossRef]

98. Kimura, A.; Namekata, K.; Guo, X.; Harada, C.; Harada, T. Neuroprotection, Growth Factors and BDNF-TrkB Signalling in Retinal Degeneration. Int. J. Mol. Sci. 2016, 17, 1584. [CrossRef] [PubMed]

99. Jin, C.; Ou, Q.; Li, Z.; Wang, J.; Zhang, J.; Tian, H.; Xu, J.Y.; Gao, F.; Lu, L.; Xu, G.T. The combination of bFGF and CHIR99021 maintains stable self-renewal of mouse adult retinal progenitor cells. Stem Cell Res. Ther. 2018, 9, 346. [CrossRef]

100. Sieving, P.A.; Caruso, R.C.; Tao, W.; Coleman, H.R.; Thompson, D.J.; Fullmer, K.R.; Bush, R.A. Ciliary neurotrophic factor (CNTF) for human retinal degeneration: Phase I trial of CNTF delivered by encapsulated cell intraocular implants. Proc. Natl. Acad. Sci. USA 2006, 103, 3896-3901. [CrossRef]

101. Ohnaka, M.; Miki, K.; Gong, Y.Y.; Stevens, R.; Iwase, T.; Hackett, S.F.; Campochiaro, P.A. Long-term expression of glial cell line-derived neurotrophic factor slows, but does not stop retinal degeneration in a model of retinitis pigmentosa. J. Neurochem. 2012, 122, 1047-1053. [CrossRef]

102. Zhao, Y.; Feng, K.; Liu, R.; Pan, J.; Zhang, L.; Lu, X. Vitamins and Mineral Supplements for Retinitis Pigmentosa. J. Ophthalmol. 2019, 2019, 8524607. [CrossRef]

103. Oliver, T.K., Jr.; Havener, W.H. Eye manifestations of chronic vitamin A intoxication. AMA Arch. Ophthalmol. 1958, 60, 19-22. [CrossRef]

104. Abe, T.; Saigo, Y.; Hojo, M.; Kano, T.; Wakusawa, R.; Tokita, Y.; Tamai, M. Protection of photoreceptor cells from phototoxicity by transplanted retinal pigment epithelial cells expressing different neurotrophic factors. Cell Transpl. 2005, 14, 799-808. [CrossRef]

105. Parmeggiani, F.; Sato, G.; De Nadai, K.; Romano, M.R.; Binotto, A.; Costagliola, C. Clinical and Rehabilitative Management of Retinitis Pigmentosa: Up-to-Date. Curr. Genom. 2011, 12, 250-259. [CrossRef]

106. Writing Group for Practice Guidelines for Diagnosis and Treatment of Genetic Diseases Medical Genetics Branch of Chinese Medical Association; Yang, Z.; Yang, J.; Zhang, Q.; Li, Y. Clinical practice guidelines for retinitis pigmentosa. Zhonghua Yi Xue Yi Chuan Xue Za Zhi 2020, 37, 295-299. [CrossRef]

107. Liu, Y.; Chen, S.J.; Li, S.Y.; Qu, L.H.; Meng, X.H.; Wang, Y.; Xu, H.W.; Liang, Z.Q.; Yin, Z.Q. Long-term safety of human retinal progenitor cell transplantation in retinitis pigmentosa patients. Stem Cell Res. Ther. 2017, 8, 209. [CrossRef] [PubMed]

108. Lu, L.; Oveson, B.C.; Jo, Y.J.; Lauer, T.W.; Usui, S.; Komeima, K.; Xie, B.; Campochiaro, P.A. Increased expression of glutathione peroxidase 4 strongly protects retina from oxidative damage. Antioxid. Redox Signal. 2009, 11, 715-724. [CrossRef] [PubMed]

109. Song, D.; Song, Y.; Hadziahmetovic, M.; Zhong, Y.; Dunaief, J.L. Systemic administration of the iron chelator deferiprone protects against light-induced photoreceptor degeneration in the mouse retina. Free Radic. Biol. Med. 2012, 53, 64-71. [CrossRef] [PubMed]

110. Liu, B.; Wang, W.; Shah, A.; Yu, M.; Liu, Y.; He, L.; Dang, J.; Yang, L.; Yan, M.; Ying, Y.; et al. Sodium iodate induces ferroptosis in human retinal pigment epithelium ARPE-19 cells. Cell Death Dis. 2021, 12, 230. [CrossRef]

111. Tang, Z.; Ju, Y.; Dai, X.; Ni, N.; Liu, Y.; Zhang, D.; Gao, H.; Sun, H.; Zhang, J.; Gu, P. HO-1-mediated ferroptosis as a target for protection against retinal pigment epithelium degeneration. Redox Biol. 2021, 43, 101971. [CrossRef]

112. Obolensky, A.; Berenshtein, E.; Lederman, M.; Bulvik, B.; Alper-Pinus, R.; Yaul, R.; Deleon, E.; Chowers, I.; Chevion, M.; Banin, E. Zinc-desferrioxamine attenuates retinal degeneration in the rd10 mouse model of retinitis pigmentosa. Free Radic. Biol. Med. 2011, 51, 1482-1491. [CrossRef] [PubMed] 
113. Wang, K.; Peng, B.; Xiao, J.; Weinreb, O.; Youdim, M.B.H.; Lin, B. Iron-Chelating Drugs Enhance Cone Photoreceptor Survival in a Mouse Model of Retinitis Pigmentosa. Investig. Ophthalmol. Vis. Sci. 2017, 58, 5287-5297. [CrossRef] [PubMed]

114. Santana-Codina, N.; Mancias, J.D. The Role of NCOA4-Mediated Ferritinophagy in Health and Disease. Pharmaceuticals 2018, 11, 114. [CrossRef] 